\title{
Single-tube nested PCR in the diagnosis of tuberculosis
}

\author{
C M Chan, K Y Yuen, K S Chan, W C Yam, K H M Yim, W F Ng, M H Ng
}

\begin{abstract}
Aims-To evaluate the usefulness of a single-tube nested polymerase chain reaction (PCR) assay in the diagnosis of tuberculosis in 1497 pulmonary and 536 extrapulmonary specimens.
\end{abstract}

Methods-A single-tube nested PCR, utilising two sets of primers with different melting temperatures $\left(88^{\circ} \mathrm{C}\right.$ for external primers; $70^{\circ} \mathrm{C}$ for internal primers) to augment sensitivity and specificity without increasing the risk of amplicon contamination, was evaluated. Specimens were initially tested for the repetitive IS6110 sequences and if negative, retested for the universal 38 kilodalton sequence and for inhibitors. dUTP/Uracil-N-glycosylase and Instagene treatment were used to minimise contamination and the effect of inhibitors, respectively.

Results-Using culture as the gold standard, the overall sensitivity of the assay was $89 \%$ for pulmonary and $42 \%$ for extrapulmonary specimens. Sensitivity varied greatly with respect to sample type $(92 \%$ for follow up specimens from a chest hospital and $70 \%$ for non-follow up specimens from a general hospital). The smear positivity rates were $15 \%$ for extrapulmonary specimens, and $69 \%$ and $45 \%$, respectively, for follow up and non-follow up specimens from pulmonary sites. Specificity was $\mathbf{9 9 . 7 \%}$. Inhibitors were present more frequently in extrapulmonary than in pulmonary specimens $(13.4 \% v 2.7 \%)$.

Conclusion-Despite the high sensitivity of the PCR assay for the diagnosis of tuberculosis in pulmonary specimens, it was less effective in the extrapulmonary samples. This is probably because of the lower bacterial load in extrapulmonary specimens, the presence of more inhibitors adversely affecting the PCR assay and the higher volume of specimens used for culture.

(f Clin Pathol 1996;49:290-294)

Keywords: tuberculosis, nested PCR, uracil-N-glycosylase.

Control of tuberculosis depends on the speedy identification of an index case, followed by appropriate treatment with or without isolation of the patient to prevent secondary transmission to susceptible contacts. Most microbiology laboratories detect Mycobacterium tuberculosis in patients with a high bacterial load by using the rapid Ziehl-Neelsen smear test and the slow culture method on Lowenstein-Jensen medium. The radiometric culture method
(BACTEC), which is comparable with guinea pig inoculation in sensitivity, is not widely used because it is expensive, hazardous and still takes 14 days to generate smear negative specimens. ${ }^{1}$ In those cases with a low bacterial load, involving either pulmonary or extrapulmonary anatomical sites, detection of antigen by enzyme linked immunosorbent assay (ELISA) ${ }^{2}$ or of tuberculostearic acid by gas liquid chromatography/mass spectrometry ${ }^{3}$ are either insensitive or non-specific. Host response as a marker for tuberculosis has been exploited in the form of the Mantoux test, ${ }^{4}$ antibody detection by ELISA $^{5}$ and the immunospot assay. ${ }^{6}$ However, these latter assays are invariably confounded by previous BCG vaccination, exposure to environmental mycobacteria and conditions which result in suppression of the immune system. The polymerase chain reaction (PCR) has been hailed by many authors as the most important recent advance that would ensure a rapid, sensitive, specific, simple and relatively inexpensive diagnosis of both multi- and paucobacillary tuberculosis. ${ }^{7-9}$ In a previous short follow up study, ${ }^{10}$ a single-step PCR assay performed well in respiratory specimens taken before and after treatment. In the present study, the performance of a single-tube nested PCR assay was thoroughly assessed in clinical specimens from pulmonary and extrapulmonary sites.

\section{Methods}

Over two and a half years, 2034 specimens were processed by the Ziehl-Neelsen smear test, culture on Lowenstein-Jensen medium and a single-tube nested PCR assay.

Pulmonary specimens included 1169 serial expectorated sputum samples collected from patients admitted for treatment of tuberculosis and 328 samples (including expectorated sputum, bronchoscopic aspirate, endotracheal aspirate, bronchoalveolar lavage fluid) from patients who were seen at the outpatient clinic or admitted to a general hospital and who had not been diagnosed with active tuberculosis.

The extrapulmonary specimens included 373 cerebrospinal fluid (CSF), 101 pleural fluid, 33 tissue, 14 peritoneal and synovial fluid, and 15 urine and buffy coat specimens. All specimens were stored at $-20^{\circ} \mathrm{C}$ if not immediately processed.

\section{SPECIMEN PROCESSING}

Pulmonary specimens

All specimens were collected in gamma irradiated disposable plastic bottles. After a 
direct smear was prepared, samples were decontaminated and digested by treatment with $3 \%$ sodium hydroxide and dithiothreitol for 30 minutes. Following neutralisation with $20 \mathrm{ml}$ $\mathrm{NaH}_{2} \mathrm{PO}_{4}$ buffer, and centrifugation at $4000 \mathrm{rpm}$ for 30 minutes, the sediment was resuspended in about 0.5 to $1 \mathrm{ml}$ buffer. Two Lowenstein-Jensen agar slants were each inoculated with about $50 \mu$ l of the sediment; $100 \mu \mathrm{l}$ of the sediment was transferred to an Eppendorf tube for DNA extraction.

\section{Extrapulmonary specimens}

All specimens were collected in either gamma irradiated plastic bottles or new glass universal bottles. Except for CSF, buffy coat and tissue specimens, all other fluid specimens were first concentrated by centrifugation at $4000 \mathrm{rpm}$ in universal bottles (Sterilin, Staffordshire, UK) for 20 minutes or at $13600 \mathrm{rpm}$ in Eppendorf tubes for 10 minutes, depending on the available volume of specimen. After decanting, about $150 \mu \mathrm{l}$ of the resuspended sediment was inoculated onto each of two Lowenstein-Jensen agar slants and a Middlebrook broth for enrichment. About $100 \mu$ l of the remaining sediment was transferred to an Eppendorf tube for DNA extraction. Tissue specimens were first homogenised by using a propylene tissue grinder (Scotlab, Shelton, USA) with proteinase $\mathrm{K}$ buffer in an Eppendorf tube ${ }^{11}$; buffy coat samples were separated from heparinised blood by dextran sedimentation before DNA extraction. For CSF specimens, the above concentration steps were often not possible because the available volume was often less than $200 \mu \mathrm{l}$. Thus, after inoculation directly into a Lowenstein-Jensen slant and 7H9 Middlebrook broth supplemented with Tween 80 , glycerol, and OADC complex (Becton Dickinson, Cockeysville, Maryland, USA), only about $50 \mu$ l was available for PCR.

\section{EXTRACTION OF DNA}

\section{Pulmonary specimens}

DNA was extracted by boiling $100 \mu$ l of the sediment with an equal volume of $1 \%$ Triton $\mathrm{X}-100$ for 30 minutes; $40 \mu \mathrm{l}$ of the supernatant was added to $160 \mu \mathrm{l}$ Instagene (BioRad, Hercules, California, USA). The mixture was resuspended three times during incubation at $56^{\circ} \mathrm{C}$ for 30 minutes. After vigorous vortexing for 10 seconds, the mixture was incubated at $95^{\circ} \mathrm{C}$ for eight minutes. After 10 seconds of vigorous vortexing and centrifugation at $13600 \mathrm{rpm}$ for three minutes, $50 \mu \mathrm{l}$ of the supernatant was used for PCR.

\section{Extrapulmonary specimens}

The sediment was resuspended in an equal volume of proteinase $\mathrm{K}$ buffer $(500 \mu \mathrm{g} / \mathrm{ml}$ proteinase $\mathrm{K}, 0.4 \mathrm{M}$ Tris, $\mathrm{pH} 8 \cdot 0,0 \cdot 1 \% \mathrm{NP}-40$, $0 \cdot 1 \%$ Tween 20 ) and incubated at $56^{\circ} \mathrm{C}$ for two hours. The reaction was stopped and bacterial lysis was achieved by boiling for 30 minutes. Inhibitors were removed as above by treatment with Instagene. Again, only $40 \mu \mathrm{l}$ of the mixture was added to $160 \mu$ Instagene and $50 \mu$ l of the supernatant was used for PCR.

PRIMERS AND PROBES USED FOR NESTED PCR AND SOUTHERN BLOT HYBRIDISATION

Two sets of primers and probes derived from the $M$ tuberculosis genome, encoding the insertion sequence IS6110 and the 38 kilodalton protein, were used. ${ }^{1213}$ The IS6110 PCR assay utilised the following sequences: external primers, position 367 to 392: 5'-CCGGCCAGCAC GCTAATAACGGTTC-3' and position 746 to 769: 5'-TGTGGCCGGATCAGCGATCG TGGT-3'); internal primers, position 455 to 472: 5'-CTGCACACTGACCGA-3' and position 670 to 652 : 5'-CGTTCGACGGTGCATCTG-3'; probe, position 537 to 566: 5'GAGCTGCGATGGCGAACTCAAGGAGCAC- $3^{\prime}$. These sets of primers and the probe were used initially to screen all specimens. If the specimen was negative with the IS6110 assay, it was retested in the 38 kilodalton assay because all of the $M$ tuberculosis isolates contained the 38 kilodalton sequence whereas $0.9 \%$ of the strains, especially those from Vietnamese patients, ${ }^{14}$ lacked IS6110. A concurrent assay was also carried with the IS6110 primers after spiking with 2 pg $M$ tuberculosis DNA extract to detect inhibitors. The 38 kilodalton protein PCR assay utilised following sequences: external primers, position 232 to 252: 5'-ACCACCGAGCGGTTCGCCTGA$3^{\prime}$ and position 648 to 628 : 5'GATCTGCGGGTCGTCCCAGGT-3'); internal primers, position 303 to 317 : 5'-TGACGTTGGCGGAGA-3' and position 539 to $524: 5^{\prime}-3^{\prime}$ AGCGGAGATGGCTA-3'; probe, position 339 to 368 : 5'-CGCTGTTCAACCTGTGGGGTCCGGCCTTTC-3').

\section{PCR CONDITIONS}

The total reaction volume was $100 \mu \mathrm{l}$ and contained the following: $10 \mathrm{mM}$ Tris- $\mathrm{HCl}$ ( $\mathrm{pH}$ 8.3) (Sigma, St Louis, Missouri, USA); $50 \mathrm{mM}$ $\mathrm{KCl} ; 2 \mathrm{mM} \mathrm{MgCl}_{2} ; 0.15 \mathrm{mM}$ dATP, dGTP, dCTP (Pharmacia Biotechology, Uppsala, Sweden), and dUTP (Boehringer Mannheim, Mannheim, Germany); 2 pmol external primers; 75 pmol internal primers; 2 units Taq polymerase (US Biochemical Corp., Cleveland, Ohio, USA); 0.5 units uracil-N-glycosylase (Boehringer Mannheim). The mixture was incubated at $37^{\circ} \mathrm{C}$ for 10 minutes to permit destruction of carry over amplicons by uracil$\mathrm{N}$-glycosylase, ${ }^{15}$ and then at $95^{\circ} \mathrm{C}$ for five minutes to inactivate this enzyme. The PCR conditions were as follows: $94^{\circ} \mathrm{C}$ for 45 seconds and $72^{\circ} \mathrm{C}$ for 1.5 minutes for the first 15 cycles for both annealing and extension in view of the high melting temperature of the external primers $\left(88^{\circ} \mathrm{C}\right)$ and then $94^{\circ} \mathrm{C}$ for 45 seconds, $55^{\circ} \mathrm{C}$ for 45 seconds and $72^{\circ} \mathrm{C}$ for one minute for 45 cycles. These PCR conditions were used for both assays. A stringent annealing temperature for the external primers is essential for the production of specific amplicons for the next 45 cycles. During re-amplification, a much lower annealing temperature was used for 
Table 1 Effect of the decontamination procedure for pulmonary specimens on the sensitivity of the PCR assay and standard culture

\begin{tabular}{|c|c|c|c|c|c|}
\hline \multirow[b]{2}{*}{ Decontamination procedure } & \multicolumn{5}{|c|}{ Limiting dilution of broth culture } \\
\hline & $10^{-2}$ & $10^{-3}$ & $10^{-4}$ & $10^{-5}$ & $10^{-6}$ \\
\hline $\begin{array}{l}\text { Decontamination with } \\
\text { normal saline (control) } \\
\text { mean cfu } 10 \mu \mathrm{l}^{*} \\
\text { proportion of positive PCR assays } \dagger\end{array}$ & $\begin{array}{l}\text { Confluent } \\
5 / 5\end{array}$ & $\begin{array}{l}>200 \\
5 / 5\end{array}$ & $\begin{array}{l}30 \\
5 / 5\end{array}$ & $\begin{array}{l}3 \\
3 / 5\end{array}$ & $\begin{array}{l}0 \\
0 / 5\end{array}$ \\
\hline $\begin{array}{l}\text { Decontamination with } \mathrm{NaOH} \\
\text { mean cfu/ } 10 \mu 1 \\
\text { proportion of positive } \mathrm{PCR} \text { assays }\end{array}$ & $\begin{array}{l}>200 \\
5 / 5\end{array}$ & $\begin{array}{l}36 \\
5 / 5\end{array}$ & $\begin{array}{l}4 \\
5 / 5\end{array}$ & $\begin{array}{l}0 \\
2 / 5\end{array}$ & $\begin{array}{l}0 \\
0 / 5 \\
\end{array}$ \\
\hline
\end{tabular}

* Colony forming units on agar medium by Miles and Misra count.

t Five PCR assays performed on $10 \mu \mathrm{l}$ aliquots of the sediment before and after decontamination

greater efficiency rather than for stringency. Positive and negative controls were included in each run and precautions against cross-contamination were taken.

DETECTION OF THE PCR PRODUCT

As previously reported, ${ }^{10} 10 \mu$ l aliquots of amplified products were electrophoresed through a $1.5 \%$ agarose gel in $0.5 \times \mathrm{TBE}$ buffer. Target
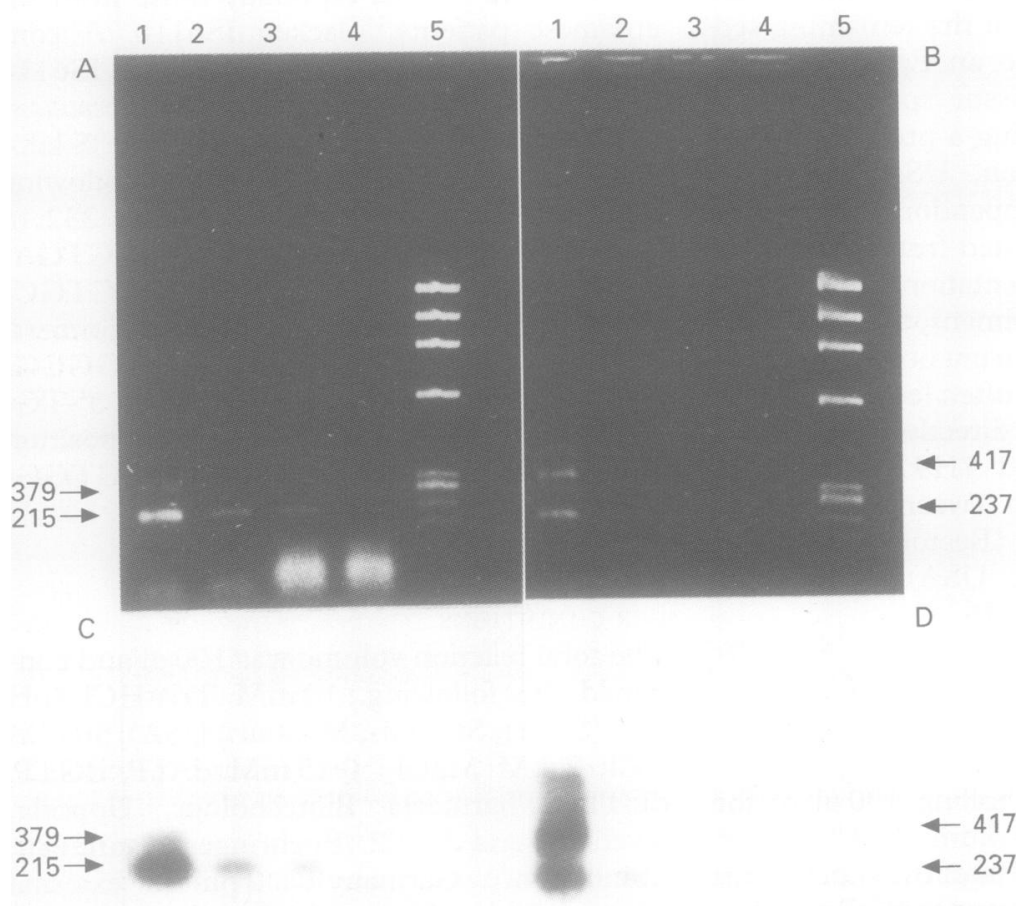

Figure 1 Panels $A$ and B, Single-tube nested PCR using the IS6110 and 38 kilodalton primers, respectively. Lanes 1-3,10-fold limiting dilution of broth culture equivalent to primers, respectively. Lanes 1-3,10-fold limiting dilution of broth culture equivalent to
about $300,30,3 \mathrm{cfu} / 10 \mathrm{\mu l}$; lane 4, negative control; lane 5, molecular weight marker $\varphi \times 174$ HaeIII digest. Panels $C$ and $D$, Southern blot hybridisation of $A$ and $B$, respectively, using digoxigenin labelled probes.

Table 2 Correlation among results of PCR assay, standard culture and clinical treatment in extrapulmonary specimens

\begin{tabular}{|c|c|c|c|}
\hline $\begin{array}{l}\text { No. and type of } \\
\text { specimen }\end{array}$ & $\begin{array}{l}\text { Culture positive for } \\
\mathrm{M} \text { tuberculosis (\%) }\end{array}$ & $\begin{array}{l}P C R \\
\text { positive (\%) }\end{array}$ & $\begin{array}{l}\text { No. of patients subsequently } \\
\text { treated for tuberculosis (\%) }\end{array}$ \\
\hline $\begin{array}{l}\text { CSF }(n=373) \\
\text { Pleural effusion } \\
(n=101)\end{array}$ & $\begin{array}{l}17(4 \cdot 6) \\
25(25)\end{array}$ & $\begin{array}{l}13(2 \cdot 4)^{*} \\
12(11)^{*}\end{array}$ & $\begin{array}{l}45(12) \\
37(37)\end{array}$ \\
\hline $\begin{array}{l}\text { Tissue }(n=33) \\
\text { Peritoneal and } \\
\text { synovial fluid } \\
(\mathrm{n}=14)\end{array}$ & $\frac{12}{2}(36)$ & $\begin{array}{l}5(15) \\
0\end{array}$ & ${ }_{5}^{18}(54 \cdot 5)$ \\
\hline $\begin{array}{l}\text { Urine }(\mathrm{n}=15) \\
(\mathrm{Sub}) \text { total } \\
(\mathrm{n}=536)(\%)\end{array}$ & ${ }_{60}^{4}(12 \cdot 3) \dagger$ & $33(6) *$ & $\begin{array}{r}5 \\
109(20 \cdot 3)\end{array}$ \\
\hline
\end{tabular}

* Five false positive results (four CSF, one pleural fluid).

† Nine specimens were smear positive. bands of 215 base pairs (bp) (IS6110 assay) and $237 \mathrm{bp}$ (38 kilodalton assay) were sought on the ethidium bromide stained gel. Further confirmation by Southern blot hybridisation was obtained with $\left[{ }^{32} \mathrm{P}\right]$ labelled probes initially and digoxigenin labelled probes (Boehringer Mannheim) in the later part of the study.

SENSITIVITY OF THE NESTED PCR ASSAY

A 14 day old Middlebrook broth culture of H37Rv supplemented with Tween 80 was serially diluted to $10^{-6}$. The viable bacterial count as ascertained by the Miles and Misra method and the presence of $M$ tuberculosis DNA as ascertained by the PCR assay after decontamination by saline (control) and 3\% $\mathrm{NaOH}$ (test) were determined from the $10^{-2}$ to $10^{-6}$ dilutions. All digestion, decontamination and concentration steps were followed (vide supra). Five PCR assays were carried out per dilution with $10 \mu \mathrm{l}$ aliquots of each sediment.

\section{Results}

In total, 1497 pulmonary specimens and 536 extrapulmonary specimens were processed using this single-tube nested PCR assay. The sensitivity of the test as shown by limiting dilution of viable bacteria and genomic DNA approached one bacteria per $10 \mu \mathrm{LNA}$ extract (table 1 and fig 1$)$. In $41(2 \cdot 7 \%)$ pulmonary specimens and $72(13.4 \%)$ extrapulmonary specimens ( $\mathrm{p}<0.05 \chi^{2}$ test), DNA purification had to be repeated using phenol/chloroform/ isoamyl alcohol or, in the later part of the study, Geneclean extraction in order to overcome the effect of inhibitors in these samples, which were PCR negative despite spiking with $2 \mathrm{pg}$ $M$ tuberculosis DNA.

Of the 373 CSF specimens, all had exudative changes with predominant lymphocytic pleocytosis but only 17 were culture positive for $M$ tuberculosis (table 2). For the remaining specimens, the final diagnoses were encephalitis $(n=52)$, brain abscess $(n=2)$, Guillain-Barré syndrome $(n=2)$, and lymphoma and carcinomatous meningitis $(n=4)$. The remaining final diagnoses included hydrocephalus, ventriculo-peritoneal shunt infection, cerebral lupus, metabolic encephalopathy, and undetermined. Forty five patients were started on empirical anti-tuberculosis treatment because of a compatible clinical picture, CSF findings and/or changes on chest $x$ ray film, 
Table 3 Performance of PCR assay in pulmonary specimens taken from different patient populations

\begin{tabular}{|c|c|c|c|c|}
\hline \multirow[b]{2}{*}{ Sample type } & \multicolumn{2}{|c|}{ Culture positive (\%) } & \multicolumn{2}{|c|}{ Culture negative } \\
\hline & $\begin{array}{l}P C R \\
\text { positive }\end{array}$ & $\begin{array}{l}P C R \\
\text { negative }\end{array}$ & $\begin{array}{l}P C R \\
\text { positive }\end{array}$ & $\begin{array}{l}P C R \\
\text { negative }\end{array}$ \\
\hline $\begin{array}{l}\text { Serial followup specimens from patients } \\
\text { diagnosed and treated for tuberculosis } \\
(n=1169)\end{array}$ & $278(91)$ & $28(9 \cdot 2)$ & 154 & 819 \\
\hline $\begin{array}{l}\text { Specimens from patients not previously } \\
\text { known to have tuberculosis }(n=329)\end{array}$ & $20(71)$ & $8(28 \cdot 6)$ & 0 & 301 \\
\hline
\end{tabular}

but only 17 of them were positive for $M$ tuberculosis on culture. Excluding the four false positive results, only nine ( $52 \%$ of all positive CSF cultures and $20 \%$ of all patients empirically treated for tuberculous meningitis) were positive by the PCR assay and all were subsequently detected by culture. The other extrapulmonary specimens such as pleural effusion, tissue, peritoneal fluid, synovial fluid, urine, and buffy coat samples were similarly investigated and the final diagnoses included carcinomatous effusion $(n=15)$, parapneumonic effusion $(n=17)$, infected ascites $(n=2)$, systemic lupus erythematosus $(n=2)$, non-specific lymphadenitis, metastatic lymphadenopathy, sarcoidosis, lymphoma, cat scratch disease, and undetermined. Sixty six patients were started on anti-tuberculosis therapy because of a positive sputum smear $(n=4)$, granulomatous changes on histology and biopsy $(n=39)$ and/ or positive culture of their extrapulmonary specimen $(n=19)$. The sensitivity of the PCR assay was only $42 \%$ when compared with culture.

With regard to the pulmonary specimens (table 3), PCR detected $M$ tuberculosis DNA in $278(92 \%)$ of 306 specimens from patients admitted to and followed up in a chest hospital but only $20(78 \%)$ of 28 specimens from patients who were seen at a general hospital and who were not known to have tuberculosis. The proportion of specimens positive for both direct smear and culture was $69 \%$ for follow up specimens but only $45 \%$ for the non-follow up specimens. As for culture negative specimens, only the follow up group exhibited the culture negative/PCR positive phenomenon $(10 \%)$, which could be attributed to the effect of drug treatment and were not false positive results. There were five false positive PCR results among the extrapulmonary specimens; the clinical picture and radiological/laboratory findings of these five patients were not compatible with tuberculosis. Four of these samples were CSF specimens and one was a pleural effusion. Retesting of the remaining DNA extracts still yielded positive results, but repeated specimens from the same patients were negative. All of these specimens had been processed for routine bacteriology before being analysed by PCR.

\section{Discussion}

The usefulness of the PCR assay for the detection of paucobacillary tuberculosis has been hailed by many authors as the most important breakthrough in the field of diagnostic myco- bacteriology. However, like many new diagnostic procedures, initial optimism was soon shattered by skepticism and gradually replaced by pragmatism. ${ }^{16}$ The present study was designed to determine the usefulness of this technique in a large-scale and comprehensive manner. The method under study was a singletube nested PCR which harnessed the different melting temperatures of the external $\left(88^{\circ} \mathrm{C}\right)$ and internal $\left(70^{\circ} \mathrm{C}\right)$ primers to increase the specificity and sensitivity of the assay without increasing the risk of contamination during reamplification. Besides the usual precautions against contamination by carry over of amplicons, the coupled use of dUTP and uracil$\mathrm{N}$-glycosylase was included and the annealing temperature was set at or above $55^{\circ} \mathrm{C}$ to prevent nicking of amplicons by residual uracil-N-glycosylase activity during the annealing step. ${ }^{15}$ Despite stringent adherence to all of these precautions, including spatial separation of the different steps of DNA extraction, PCR and amplicon detection, and the use of ultraviolet light to destroy contaminating amplicons and uracil-N-glycosylase, five false positive results were obtained for extrapulmonary specimens. We believed that the manipulation of these CSF and pleural fluid specimens with re-used pipettes in the routine bacteriology laboratory might have introduced mycobacterial DNA. This was because these five specimens were not originally sent with a request for PCR but for routine bacteriology culture or cryptococcal antigen detection.

The sensitivity of the PCR assay varied greatly between the pulmonary $(89 \%)$ and extrapulmonary specimens $(42 \%)$, with culture as the gold standard. This disappointing finding was related to the available amount of $M$ tuberculosis in the clinical specimen, the amount of accompanying inhibitors, the relative volumes of sediment used for PCR and culture, after the decontamination procedure and the inclusion of dUTP and uracil-N-glycosylase in the PCR reaction. ${ }^{17} \mathrm{Up}$ to $67 \%$ of the culture positive sputum specimens, but only $15 \%$ of the culture positive extrapulmonary specimens, were smear positive (table 2). This is because up to $10^{9}$ bacteria can be present in cavitating pulmonary lesions. The bacterial load in the subarachnoid space, and pleural, peritoneal and joint cavities is much lower. Moreover, inhibitors are found more frequently in extrapulmonary $(13.4 \%)$ than in pulmonary specimens $(2 \cdot 7 \%),{ }^{18}$ which is surprising given that CSF and pleural effusion samples have often been regarded as homogeneous and easy to handle. During the process of digestion and decontamination, $\mathrm{NaOH}$ lysed most eukaryotic cells and probably denatured many inhibitory proteins such as haemoglobin. On neutralisation, the buffer also dilutes out any residual inhibitory substances. This process could not be used in the extrapulmonary specimens as it would lead to further loss of the scanty amount of $M$ tuberculosis DNA.

The use of culture as the gold standard in the study for PCR evaluation had a number of implications. The number of viable $M$ tuberculosis present in the inoculum was the most 
important factor affecting culture, while both viable and non-viable bacteria were equally important as the determinants of sensitivity of the PCR assay, although apparently reducing specificity. As shown in table 1 , in pulmonary specimens up to $90 \%$ of bacteria were rendered non-viable by the decontamination procedures. Thus, the sensitivity of PCR was comparable with culture although only $12 \cdot 5 \mu \mathrm{l}$ and $100 \mu \mathrm{l}$, respectively, of the sediment were used for PCR and culture. This was not the case in extrapulmonary specimens, which did not undergo decontamination and of which the volume of sediment that could be used for culture often noticeably higher than that used for PCR, greatly enhancing the apparent sensitivity of culture compared with PCR in these specimens. It is not possible to increase the volume of sediment used for PCR further because the problem of inhibitors would then be insurmountable. Moreover, the sensitivity of culture was further augmented by an enrichment broth culture in extrapulmonary specimens because there was little risk of contamination by other bacteria. Apart from the above reasons, Pang et al ${ }^{17}$ reported that the use of dUTP and uracil-N-glycosylase may result in loss of assay sensitivity by a factor of 10 . This might counteract the nested PCR effect and explain one of the causes of diminished sensitivity in paucobacillary extrapulmonary samples. However, the low frequency of false positives justified its inclusion.

PCR was more sensitive in samples from patients with known tuberculosis admitted to a chest hospital for treatment than in undiagnosed patients first seen at a general hospital. As expected, the smear positive rate was higher amongst the culture positive specimens in the former group of patients (69v $45 \%)$. The phenomenon of culture negative/PCR positive specimens has been reported previously. ${ }^{710}$

After many reports of the excellent performance of the PCR assay in the diagnosis of pulmonary tuberculosis, similar good results were expected in the diagnosis of extrapulmonary tuberculosis. These expectations were not met in this study because of many different confounding factors. Further studies must be conducted to improve these deficiencies. A higher volume of starting material must be used in view of the paucobacillary nature of extrapulmonary tuberculosis. A better extraction procedure which could capture all the $M$ tuberculosis DNA, but not inhibitors, must be developed-for example, the immunomagnetic separation technique. ${ }^{19}$ Other resin matrix preparations which absorb inhibitors such as Genereleaser and which do not entail further loss of DNA may also be used. ${ }^{20}$ Besides repetitive sequences, amplification of ribosomal RNA may produce better results as thousands of copies are present per bacteria. ${ }^{21}$ Finally, more sensitive detection formats such as probe signal amplification techniques should be considered. ${ }^{22}$
We are grateful to the clinical laboratory staff of the Department of Microbiology, The University of Hong Kong, especially Ms Yvonne Chiu, Mr K H Chan, Mr W T Hui, and Mr Raymond Leung.

The research is funded by the Research Grant Council (Grant No. HKU 333/93M), Hong Kong.

1 Morgan MA, Horstmeier CD, DeYoung DR, Roberts GD Comparison of a radiometric method (BACTEC) and conventional culture media for recovery of mycobacteria from smear-negative specimens. $\mathcal{f}$ Clin Microbiol 1983;18 384-8.

2 Sada E, Ruiz-Palacios GM, Lopez-Vidal Y, Ponce-de-Leon $S$. Detection of mycobacterial antigen in cerebrospinal fluid of patients with tuberculous meningitis by enzyme linked immunosorbent assay. Lancet 1983;i:651-2.

3 Yew WW, Chan CY, Kwan SY, Cheung SW, French GL. Diagnosis of tuberculous pleural effusion by the detection of tuberculostearic acid in pleural aspirates. Chest 1992 102:1635-6.

4 American Thoracic Society and Centers for Disease Control The tuberculin skin test. Am Rev Respir Dis 1981;124: $356-63$.

5 Grange JM. The humoral immune response in tuberculosis: its nature, biological role, and diagnostic usefulness. $A d v$ Tuberc Res 1984;21:1-78.

$6 \mathrm{Lu} \mathrm{CZ}$, Qiao J, Shen T, Link H. Early diagnosis of tuberculosis meningitis by detection of anti-BCG secreting cells in cerebrospinal fluid. Lancet 1990;336:10-13.

7 Pierre C, Lecossier D, Boussougant Y, Bocart D, Joly V, Yeni $P$, et al. Use of a reamplification protocol improve sensitivity of detection of Mycobacterium tuberculosis in clinical samples by amplification of DNA. $\mathcal{F}$ Clin Microbiol 1991;29:712-17.

8 Shawer RM, El-Zaatari AK, Nataraj A, Clarridge JE. Detection of Mycobacterium tuberculosis in clinical samples by twidistion methods. F Clin Micmbiol 1993:31:61-5.

9 Wilson SM, Nava E, Morales A, Godfrey-Faussett P, Gillespie S, Andersson N. Simplification of the polymerase chain reaction for detection of Mycobacterium merase chain reaction for detection of Mycobacterium tuberculosis in the

10 Yuen KY, Chan KS, Chan CM, Ho BSW, Dai LK, Chau PY, et al. Use of PCR in routine diagnosis of treated and untreated pulmonary tuberculosis. F Clin Pathol 1993;46: $318-22$.

11 Ghossein RA, Ross DG, Salomon RN, Rabson A. Rapid detection and species identification of mycobacteria in paraffin-embedded tissue by polymerase chain reaction. Diagnostic Molecular Pathology 1992;1:185-91.

12 Thierry D, Cave MD, Eisenach KD, Crawford JT, Bates $\mathrm{JH}$, Gicquel B, et al. IS6110, an IS-like element of Myco-
bacterium tuberculosis complex. Nucleic Acids Res 1990; 18: 188 .

13 Bengard Andersen A, Hanse EB. Structure and mapping of antigenic domains of protein antigen $b$, a 38,000 molecular weight protein of Mycobacterium tuberculosis. Infect Immun 1989;57:2481-8.

14 Yuen LK, Ross BC, Jackson KM, Dwyer B. Characterisation of Mycobacterium tuberculosis strains from Vietnamese patients by Southern blot hybridisation. $\mathcal{f}$ Clin Microbiol 1993;31:1615-18.

15 Longo MC, Berninger MS, Hartley JL. Use of Uracil DNA glycosylase to control carry-over contamination in polymerase chain reactions. Gene 1990;93:125-8.

16 Noordhoek GT, Kolk AHJ, Bjune G, Catty D, Dale JW, Fine $\mathrm{PE}$, et al. Sensitivity and specificity of $\mathrm{PCR}$ for detection of Mycobacterium tuberculosis: a blind comparison study among seven laboratories. $\mathcal{f}$ Clin Microbio 1994;32:277-84.

17 Pang J, Modlin J, Yolken R. Use of modified nucleotides and uracil-DNA glycosylase (UNG) for the control of contamination in the PCR-based amplification of RNA. Mol Cell Probes 1992;6:251-6.

18 Brisson-Noel A, Aznar C, Churea C, Nguyen S, Pierre C, Bartoli M, et al. Diagnosis of tuberculosis by DNA amplification: clinical practice evaluation. Lancet 1991; 338:364-6.

19 Widjojoatmodjo MN, Fluit AC, Torensma R, Verdonk GP, Verhoef J. The magnetic immuno PCR assay for direct detection of salmonellae in fecal samples. $¥$ Clin Micmbiol detection of salm

20 Amicosante M, Richeldi L, Trenti G, Paone G, Campa M Bisetti A, et al. Inactivation of polymerase inhibitors fo Mycobacterium tuberculosis DNA amplification in sputum by using capture resin. $\mathcal{F}$ Clin Microbiol 1995;33 629-30.

21 Jonas V, Alden MJ, Curry JI, Kamisango K, Knott CA Lankford R, et al. Detection and identification of Mycobacterium tuberculosis directly from sputum sediments by amplification of rRNA. $\mathcal{F}$ Clin Microbiol 1993;31:2410-6.

22 Sanchez-Poscador R, Stempien MS, Urdea MS. Rapid chemiluminescent nucleic acid assays for the detection of TEM-1-beta-lactamase-mediated penicillin resistance in Neisseria gonorrhoeae and other bacteria. 7 Clin Microbiol 1988;26:1934-8. 